\title{
MĀORI STUDENTS' EXPERIENCES OF THEIR MĀORI IDENTITY IN A BACHELOR OF PHYSICAL EDUCATION
}

\author{
Rochai Taiaroa* \\ Wayne Smith ${ }^{\dagger}$
}

\begin{abstract}
This article presents the findings of a research project that examined six Māori students' perceptions of how their Māori identity impacted on their experiences in a four-year Bachelor of Physical Education (BPE) programme. The BPE programme is positioned in a faculty of education situated in Auckland, Aotearoa New Zealand, and has an annual intake of approximately 60-70 students. On average $20 \%$ of these identify as Māori. The research process involved both individual and group interviews conducted by the first author, who asked the students what Māori identity meant to them, and how they sensed their Māori identity had impacted on their experience of the BPE programme. The students willingly shared their views as Māori, providing insight into how they sensed they were perceived by their lecturers and peers. They also expressed their desires and needs as Māori students. Whilst these six research participants appreciated the lecturers' attempts to introduce bicultural pedagogy, to use te reo and integrate tikanga Māori into their teaching, they also felt the need for more identifiable Māori role models and mentors. This led the students to desire more Māori lecturing staff who could provide authentic Māori learning experiences, especially in courses that focused on Māori content.
\end{abstract}

* Ngati Raukawa, Ngati Kahungunu, Tuwharetoa, Kai Tahu. Professional Teaching Fellow, Faculty of Education and Social Work, University of Auckland, New Zealand. Email: r.taiaroa@auckland.ac.nz

$\dagger$ Associate Professor, Faculty of Education and Social Work, University of Auckland, Auckland, New Zealand.

DOI: 10.20507/MAIJournal.2017.6.1.2 


\section{Keywords}

Māori student experiences, language, culture, role models, whānau, physical education teacher education

Ko tōu reo, ko tōku reo, te tuakiri tangata. Tīhei uriuri, tîhei nakonako.

Your voice and my voice are expressions of identity.

May our descendants live on and our hopes be fulfilled.

\section{Introduction and contextual background}

In 2013, 36,072 New Zealanders who selfidentified as Māori had a bachelor's degree or higher, compared to just 23,070 in 2006 (Statistics New Zealand, 2013). This was an increase of $56.4 \%$ over seven years and a strong indicator of the growing number of Māori entering tertiary education. Whilst this is an encouraging sign, as Gorinski and Abernethy (2007) have reported, many Māori tertiary students experience barriers to learning due to negative stereotyping of identity and ability.

With this background in mind, this article draws on the findings of a research project that aimed to find out if this pattern of negative stereotyping was reflected in the experiences of Māori students in a four-year Bachelor of Physical Education (BPE) programme in Auckland, Aotearoa New Zealand. The project grew out of the first author's own experiences as a Māori tertiary student and later a Māori learning support person in a tertiary institution. As a Māori engaged in undergraduate tertiary study, she was an ethnic minority in her university classes and was keenly aware of how her Māori identity influenced her engagement in university life.

As a Māori tertiary student she gained a greater appreciation of the dominant social group's power to prescribe the norms of identity, behaviour, language, social relations and lifestyle, and how this power determines who become "insiders" and who are considered to be "outsiders" (Rata et al., 2001). On a number of occasions during her undergraduate university experience she felt like an outsider who needed to explain and defend her culture. These experiences enabled her to become more aware of how her Māori identity was shaping her tertiary education experiences, and of how those experiences were shaping her own identity.

Informed initially by her undergraduate tertiary student experiences and later by postgraduate study, the first author (while in the role of Student Support Advisor [Māori] at the same university under study) sought to investigate how six Māori students felt their Māori identity had impacted on their learning experiences in an undergraduate teacher education programme. During initial individual interviews the researcher asked the students to reflect on their identity as Māori, and then in subsequent individual, pair and group interviews asked how they perceived their identity as Māori had impacted on their years in the BPE programme.

Taught within a faculty of education, the BPE degree is a four-year undergraduate health and physical education programme that integrates substantive physical education subject knowledge, subject matter content knowledge and professional teacher education components. Its primary role since 1968 has been to prepare teachers of health and physical education for New Zealand secondary schools (Smith, 2008). As such, the programme is an approved teacher education programme that enables graduates to qualify as provisionally registered teachers in Aotearoa New Zealand via a government approving agency. Although it includes the disciplines of sport and exercise 
science and critical social science, its primary disciplinary foundation is education. The university in which the BPE degree is located has a separate Department of Sports and Exercise Science located in the Faculty of Science, which has exercise science as its main focus. The programmes run by each department are not linked in any way.

Underpinned by this educational focus, the conceptual framework of the BPE programme is grounded in the theory and practice of learning and teaching. The programme approval documents provide an example of the programme's philosophy:

Traditionally, the nature of physical education at tertiary level has been fractionated by competing discourses. The central thesis of this programme is the contention that physical education is firmly grounded within an educational context and, as such, must be treated as a professional activity. Thus the synthesis of physical education content knowledge, professional inquiry and practice, and reflection are central tenets of this degree programme. (Smith, 2008, p. 44)

Having presented this background, we now provide a brief overview of the elements of the programme that specifically focus on Māori content. One academic, who recognised the need for bicultural content, developed much of this content. In the early 1990s, Maureen Legge (2008), a Pākehā educator in the BPE programme, introduced two dedicated Māoricontent courses after she "recognised the need to include Māoritanga in the curriculum content of physical education teacher education in Aotearoa/New Zealand" (p. 87). The first of these courses was an introductory paper in which she introduced the students to Te Ao Kori in order to emphasise bicultural identity and multiculturalism. The term Te Ao Kori aims to capture a Māori worldview encompassing a holistic understanding of the body, mind and spirit, and the associated health and physical education practices of Māori traditions, recreational games and pastimes (Legge, 2008).

In the second year Legge (2008) introduced a more challenging, critically focused paper that asked the students to reflect on their own identity and to think about identity from a Māori worldview. This paper included a five-day marae stay. As Legge says, the marae stay was introduced because she felt the students needed closer contact with Māori culture to increase their bicultural identity. This was because she realised that few of the students had access to Māori culture in authentic ways. Perhaps more altruistically and ambitiously, she sought to “ask non-Māori to reflect on their attitudes relating to Māori and the colonisation process, to discover their identity; and to understand that facing up to cultural difference is a personal challenge in which we all have agency" (Legge, 2008, p. 87).

In Legge's (2008) own published reflections she comments on the challenges students typically encounter through their firsthand noho marae experiences. She particularly notes how it challenges Pākehā students to reflect on their dominant Pākehā hegemony and locate their personal identity, cultural differences and understanding of the world alongside a Māori worldview. This, she says, can be a "bumpy ride of cultural discomfort because of misunderstandings about histories, colonisation and the effect of alienation from the land and loss of cultural identity" (p. 89).

In the context of the findings of this paper, it is important to highlight what Legge (2008) saw as the legacy of the noho marae stays after 11 years of involvement:

The educative outcome of my EOTC [noho marae] work has intensified into supporting Māori identity with my strong belief that it is important for all of my students to see, that their future teaching persona must recognise and develop an increased understanding of bicultural awareness to back up interactions with their peers.... The breakdown by their 
apparently steady, stable classmates while staying on the marae highlights that this is more than a necessity-it is essential. (p. 98)

We now outline the methods used in this research project, a project that aimed to gain insight into the perceptions of six Māori students who had personally experienced the BPE programme.

\section{Methodology}

The student participants in this research project were selected, using purposive sampling, on the basis that they self-identified as Māori and were in the final two years of the four-year BPE programme. Six students took part in the project; four were female and two were male. In accordance with the university ethics approval conditions, pseudonyms have been used to ensure the students' anonymity.

Critical ethnographic methods were employed to gain rich information about the participants' perspectives. Ethnographic methodology is a process that provides rich descriptive data about the contexts, activities and beliefs of participants (Giles, 1995). Critical ethnography goes a step further, requiring the researcher to examine the findings within the context of broader social issues (Smith, 1999). In addition, as both the researcher and all participants were Māori, Kaupapa Māori (KM) theory was used as a governing framework to establish trust and empathy between the researcher and the participants. KM theory places a Māori worldview at the centre of the research. It involves theorising that requires an esoteric understanding of tikanga Māori. It is as much a philosophical approach as it is a methodology because it asks the researcher to "think Māori" and to articulate the findings of the research from a Māori worldview (Pihama, 2001). While KM theory engages with other forms of knowledge construction, it centres itself in mātauranga Māori (Walker, 1989). Mātauranga Māori is the holistic and overarching position that holds and connects the threads of customary and contemporary Māori knowledge, which includes tikanga and kaupapa among its threads (Taiaroa, 2007).

The empirical evidence and interpretation of this evidence were drawn from the stories of the students. Each participant was individually interviewed on two separate occasions using semi-structured interviews (however, two of the students chose to be interviewed together, and in keeping with KM principles, this was permitted). The first interview focused on the students' identity, background and personal beliefs and the second focused specifically on their experiences in the BPE programme. Using a semi-structured format, the students were asked the following questions, with more probing questions following when the researcher considered it necessary to elicit more information:

- Describe your background and involvement in the Māori community.

- Is Māori language important?

- Is involvement in Māori community important to you?

- What is your knowledge of your own iwi, hapū, marae?

- What is 'Māori identity' according to you?

- Can you say how you express or experience your Māori identity?

- How have you experienced your Māori identity in the physical education programme?

- How has your sense of being Māori been developed or suppressed in the programme?

- Can you remember any experiences that have had an influence on your Māori identity? Describe them and how they worked for you.

- Since your enrolment in the programme do you think your Māori identity has developed in any way, other than through the programme itself? Explain how.

- Can you name any Māori facilities on campus? Do they make a difference to your identity as a Māori? 
- Do you think students/lecturers make assumptions about Māori PE students? If so what are they?

Following the analysis of the initial interviews a focus group interview was held with all of the participants. Focus group interviews allow the interviewer to elicit further information from or clarify previous information with the participants. During this focus group the participants' initial question responses were raised and further discussed as a collective. This allowed other students to hear and to add to or question the researchers' interpretation of the initial interview information.

\section{Literature review}

A literature review was begun before the interview process and continued during data collection. This focused on cultural identity and what it means to be Māori to provide a sense of understanding of the multiple influences that impact on identity, including one's ethnic heritage. Thus, in what follows we present a brief overview of how Māori identity has been defined before presenting our findings relating to the students' interpretations of their Māori identity.

As Walker (1989) argued, for many Māori identity is derived from one's membership of "recognised corporate groups ranging in size from the whānau to hapū, iwi, and waka" (p. 38). For Māori, personal identity and social identity are one and the same, meaning one exists as a part of a whānau, hapū or iwi just as much as one exists as an individual.

Even in today's world, Māori identify with their iwi more readily than the Pākehā-initiated label "Māori". The labelling of Māori as a pan-tribal group only came about following British colonisation of Aotearoa as a means of classifying the total Indigenous population (Broughton, 1993). This established an either/ or dualism of Māori or Pākehā, Indigenous/ tangata whenua or non-Indigenous, and with this came customary and cultural divides and ultimately a clash of values and traditions.

As time has progressed and ethnic differences have become less distinct, new ways of recognising and seeking Māori identity, and indeed Pākehā identity, have evolved. Integration of the two ethnic groups has led some Māori, such as Ritchie (1963), to advocate for formally recognised descriptors of Māori identity. Many of these descriptors are based on ancestral lineage and adherence to traditional cultural values and practices. But this has created problems for those who identify with other ethnicities as well as Māori, who experienced urbanisation and the dislocation from whānau and whenua as a result.

A post-World War II societal change in Aotearoa New Zealand saw a significant shift in Māori cultural identity as many Māori moved away from their traditional rural homelands in search of work and an urban lifestyle in the cities (Barcham, 1998). This shift from rural to urban environments led to a new form of Māori identity, that of the "urban Māori", which continues today. Typically, urban Māori live in the city and return to their rural marae for whānau events such as tangihanga.

With the ongoing integration of different ethnic groups, many individuals who identify as Māori are ethnically diverse, and this has led to personal identification struggles for some (Meredith, 2004). As Webber (2008) argued, these "hybrid identities" have led to labels and identities such as "half-caste", such that many Māori of mixed descent struggle to identify themselves and find sanctuary in either Māori or Pākehā society. Since the late 1960s the mix of ethnicities has become more complex and personal identity more difficult to define as Aotearoa New Zealand has become the home of choice for many Pacific people and increasingly other immigrant groups.

McIntosh's (2005) and Borell's (2005) research describes how contemporary urban Māori experience their fusion or hybrid ethnic 
identity. Both argue that whilst cultural values and traditions are important to Māori identity formation, so too is a strong sense of belonging to a community that has shared life experiences and values. Such communities, as Borell found in South Auckland, provide an enduring sense of affinity, affiliation, solidarity and collectiveness, and in turn a sense of security and belonging.

In this way, both McIntosh (2005) and Borell (2005) help us to recognise and appreciate that identity formation has multiple axes such as ethnicity, gender, class, sexuality, occupation and location. They also remind us that whilst traditional identity makers have "many inclusionary mechanisms that allow Māori to find a valued place for themselves ... they also create space for some exclusionary mechanisms" (Mcintosh, 2005, p. 44). Borell (2005) argues that a risk of using relatively unyielding identity markers is that "Māori who are not deeply or actively steeped in such recognised dimensions of Māori culture are often invisible, their identity markers as Māori are misunderstood and as a result many are doubly maginalised" (p. 195).

The multi-ethnic diversity of New Zealand society led M. H. Durie (1995) to create a more contemporary construct of Māori identity, that of self-identity. The idea of self-identification is a relatively new one for Māori but, as Durie argues, people and groups are best able to articulate their own positions, values and beliefs. $\mathrm{He}$ adds that imposed stereotypes create misleading impressions and misrecognise that individuals wish to move in particular ethnic or cultural directions.

Before presenting the self-identifying and personal stories of the Māori student participants in this research, we provide a brief overview of the literature that supports the inclusion of Indigenous cultures in tertiary study.

\section{The importance of cultural inclusion in tertiary study}

Previous literature relating to Māori and other Indigenous student experiences in tertiary study presents a very strong case for the inclusion of Indigenous knowledges and values. For example, D. G. Smith (1991, as cited in Gorinski \& Abernethy, 2007), argued that programmes of study need to acknowledge the diversity of the student body and value the experience and knowledge of their non-mainstream students to reduce student alienation.

Bishop, Berryman and Richardson (2002) argued that New Zealand tertiary education providers need to create a culturally inclusive curriculum for Māori and minority students. They explicitly identified acknowledgement of their prior learning, their values and experiences, and their traditions and cultural icons as determinants of success. More specifically, Hokowhitu (2004), a Māori health and physical education academic, argued that one way "to create an inclusive curricula is for lecturers to challenge the assumptions ... that physical education has a history of inclusiveness towards things Māori” (p. 76). Hokowhitu's view reflects M. H. Durie's (2003) belief that the first goal of education should be consistent with the goal of enabling Māori to live as Māori, which "means being able to have access to Te Ao Māori, the Māori world—access to language, culture, marae (tribal or community cultural centres), tikanga (customs), and resources such as land, whānau, and kai moana (seafood)" (p. 199).

The above call for the inclusion of Indigenous cultures is reflected in international studies of tertiary programmes. Shield (2004), for example, reported the experiences of a number of American Indian students in a mid-Western university in the United States. Shield found that American Indian students were successful in their tertiary studies when they "used their ethnic identity as a form of social-psychological anchor” (p. 115). These students found a sense 
of confidence and security in their American Indian ethnicity. In addition, although they recognised the value of their university qualification, they strongly identified with traditional American Indian culture and did not aspire to be assimilated.

Shield (2004) criticised strategies that aimed to increase retention among American Indian students in higher education through assimilation processes. She argued that approaches that provide additional support to "help" Indigenous students to gain success often disregard the essence of their "Indianess". Again, she emphasised, when American Indians are encouraged to retain their Indigenous identities, values and ways of being in the world as American Indians, they are more successful. Nakhid (2006) summed this up in lamenting the fact that "universities maintain existing inequalities and the dominance of particular cultures by treating everyone the same" (p. 301), thereby failing to acknowledge how they serve the interests of the dominant groups at the expense of their minority students.

The findings from Shield (2004) and observations from Nakhid (2006) strongly support the need to include Māori cultural values and practices in tertiary programmes of study, and encourage Māori students to gain strength from their own Māori ethnic identity. We now present how our student participants self-identified as Māori and hear their stories of their tertiary experiences.

\section{Findings and discussion}

Five of the six participants of this research project saw themselves not only as students but also as Māori students. Aroha and Tama had a strong sense of being Māori. Aroha had been immersed in Māori culture and had attended Kōhanga reo and Kura Kaupapa Māori from a young age. Tama was surrounded by whānau members who were immersed in Māoritanga and assisted with te reo acquisition through a local iwi radio station. One other, Anahera, had limited knowledge of te reo but strong Māori identification. Rangi and Kahurangi, meanwhile, had an embodied Māori identity but little to no knowledge of te reo Māori and limited exposure to Māori culture. However, they all recognised that their ethnicity enabled them to be part of a collective whānau and to feel safe, and even empowered when in the whānau group with other Māori and Pacific students of their cohort year. The inclusion of Pacific students here supports Borell's (2005) findings that in South Auckland at least, Māori and Pacific often share a sense of collective belonging due to their common contextual life experiences.

In contrast, one of the participants, Hera, was not outwardly identifiable as Māori, even though she self-identified as Māori due to her ancestral heritage. Hera was fair-skinned and had no other visible Māori ethnic markers. She did not identify with her Māori peers or mix in their whānau group. Whereas the skin colour of the other Māori participants provided visible signs of their Māori identity and accepted Māori ethnicity to the point that it was not questioned, this was not so for Hera. Her Māori ethnicity was hidden from the view of outsiders and when, as a child, she declared her Māori ethnicity it was constantly questioned, to the extent that through her childhood she had become socialised into adopting a predominantly Pākehā lifestyle, which she now led to the exclusion of Māori cultural practices. She expressed some frustration with the trials she had had to face because she did not fit the normal stereotype of what a Māori person looks like:

I was told I wasn't Māori enough and I think that kind of set me back a bit and kind of made me go well maybe I shouldn't identify as Māori. Yeah it was kind of (I think) that probably pushed me away from it a little bit, yeah. (Interview, June 6, 2013)

Hera also expressed the view that she was not readily accepted as being Māori by the other 
Māori students because she did not have much in common with them or socialise with them:

But then at the same time I've never been one of them. I'm talking about them like they're not part of me but like just that group of people and I've hardly seen them in the classroom. (Interview, June 6, 2013)

We can see in Hera's case how her nonidentification with the traditional markers of Māori identity has been exclusionary for her, just as McIntosh's (2005) and Borell's (2005) research suggests.

The other five Māori students were, however, always conscious of their Māori identity and just as conscious of generalisations that others make of Māori. Drawing from the students' interviews, we now present how they viewed their experiences of their Māori identity in the BPE programme.

The first significant Māori identity marker among this group was the strength they gained from one another's support and friendship. They acknowledged this as the strength of the whānau, using the notion of whānau or family in its broadest sense to mean their friendship group. The students used their whānau group to support each other through their studies, but they also recognised that the group did not have to be solely composed of Māori students. Again, here we see the need for a collective sense of affinity, affiliation and belonging. They added that as members of the whānau group all individuals did have to embrace common beliefs and shared values. Kahurangi expressed it this way:

I think because we can relate, you know, we have that relationship where we don't compete with each other, we kind of like help each other. I think that's where it shines through. Like we're very whānau orientated. (Interview, May 24, 2013)

Hera, although having previously stated that she was not part of it, similarly recognised the shared strength of the whānau:

$$
\begin{aligned}
& \text {... that sense of, like, community around you } \\
& \text { like you're not just one person. There's always } \\
& \text { more than one person and there's always more } \\
& \text { than one person to think about. Like there's } \\
& \text { never just you there's always more than just } \\
& \text { you and those connections are really impor- } \\
& \text { tant, yeah. (Interview, June 6, 2013) }
\end{aligned}
$$

We can see in the above comments similarities with Shield's findings with American Indian students, in that these Māori students also find a social-psychological anchor in their shared ethnicity and collective experiences. However, it was even more important that the whānau have shared cultural values of support and camaraderie. Previously, Greenwood and Brown (2008) showed that whanaungatanga relationships repeatedly emerged as a central strength for Māori students:

$$
\begin{aligned}
& \text { Whanaungatanga describes not only relation- } \\
& \text { ships, but also the obligations and expectations } \\
& \text { that come through relationships, and the inter- } \\
& \text { dependence of the group. With relationships } \\
& \text { comes an expectation of manaakitanga, the } \\
& \text { practical application of respect, support and } \\
& \text { nurturing. (p. } 75 \text { ) }
\end{aligned}
$$

A second important Māori identifier was the use of te reo. All six Māori students, including Hera, believed that the use of te reo was important to their identity, even if they themselves were not proficient in the language. Just two participants were proficient in te reo, while the other four had either no reo or limited Māori-language skills. Despite, for most, their own limited skills, they believed the use of te reo in their classes was important because it allowed them to connect to their cultural identity and at the same time implicitly gain a sense of belonging in the class. As Aroha, a fluent te reo speaker, said, "Language is important because it's part of history, it's what your ancestors spoke and I guess 
respect and the highest respect to your ancestors would be speaking the language" (Interview, May 24, 2013). Similarly Anahera, a student with limited te reo, stated:

... language is something that could hold forever ... te reo Māori could be your strength ... I see people who can speak te reo Māori and I'm like I aspire to be like that. Like I think that is what makes a huge difference between Māori that just say yes I'm Māori and then there's Māori who really are immersed in it, you know your te reo, you're going back to your roots, you know, it's respect for your ancestors. (Interview, June 26, 2013)

The students particularly appreciated that some lecturing staff attempted to incorporate te reo Māori into their teaching. Although they did not expect the lecturers to be experts, they respected their efforts to use the language. This view supports a finding of Bevan-Brown (2003), who argued that although teachers do not need to be multicultural experts, they should have a "working knowledge" of the cultures of their students, and be able, for example, to incorporate basic te reo into their daily teaching. Tama appreciated that one of her lecturers used te reo. She stated that her lecturer "uses Māori as a tool of teaching, so a style of teaching which is cool. So the [lecturer] goes e noho, haere mai, e tu" (Interview, June 19, 2013).

The integration of Māori cultural knowledge and customs into some of their courses was another cultural practice that was seen to be inclusive for these Māori students. This was because it validated such knowledge and customs and in turn allowed them to connect with their Māori identity. Aroha expressed this in the following way: "Having a Māori paper you get to read in class makes you more connected and you can be really passionate about talking about it because that's who you are" (Interview, June 19, 2013).

The use of te reo and the inclusion of Māori content knowledge in the teaching and learning environment is what Pihama (2001) called a KM perspective. She argued that language and culture are part of the lived realities of Māori; that the bond between the two is unbreakable and therefore the culture is expressed in the use of the language and should be encouraged in all learning environments.

Like most students, these Māori students desired role models with whom they could readily identify, and for this reason they wanted more Māori lecturers. But it was not just because these Māori lecturers would be good role models; the students perceived that they would be better mentors to them as Māori students. The students felt that they would more readily approach Māori staff than Pākehā lecturers because they believed they would be heard without the lecturer having a preconceived prejudice or judgement about their ability as students. Here again we see the seeking of a social-psychological anchor that a shared ethnicity provides. Hera expressed it this way:

I think that Māori students probably identify better with a Māori educator rather than someone that's not because they can understand them a bit more on a bit more of a personal level, yeah ... [The lecturer] being not Māori doesn't understand necessarily where if you are Māori you're coming from. (Interview, June 6, 2013)

Anahera also described her perceptions of how her lecturers and fellow students perceived her and other Māori students:

So I feel that a roundabout assumption is that Māori need more help, which I do. Like, I do need more help but I guess that is an argument. Some people see it as being, you know, offensive to some Māori. Whether they're making a judgement because they thought I was dumb just in general or whether they thought I was dumb because I was Māori I'm not sure, but that was one thing that I was kind of like, I kind of stepped back and I was 
like, "Well what are you saying?" (Interview, June 26, 2013)

The student participants also believed that having Māori lecturers was especially important and in fact essential in the specifically designated Māori courses they studied. In this BPE programme, these courses were taught by Pākehā and the student participants argued that even though the Pākehā lecturers embraced bicultural perspectives, this was not enough for them. They felt that only Māori have a truly embodied understanding of what it is like to be Māori and therefore only Māori lecturers could and should teach these specialist courses. In addressing this, Aroha stated: "I guess if you teach Māori you should be Māori. Only because the information is distorted otherwise if taught by non-Māori” (Interview, May 24, 2013). Kahurangi added:

I believe if a Māori were to take the papers it would make a difference I'm just saying that from my point of view the lecturers don't have that Māori aura. If you're Māori you should understand the Māori background for us being Māori the lecturers don't. (Interview, May 24, 2013)

Anahera also felt this way, stating:

I feel like it would be really cool to have a Māori lecturer taking the Māori papers. I have nothing against non-Māori taking stuff but I felt like other students could have benefitted more from having a Māori lecturer because of pronunciation and general protocol and I know the lecturers try so hard like you can see that. (Interview, June 26, 2013)

These comments highlight the complexity of the education environment. The students desired the authenticity that a Māori educator could bring to the Māori content courses but at the same time recognised the need for all staff (Māori and non-Māori) to embrace and promote te reo and tikanga. This complexity is discussed further in the conclusion below.

\section{Conclusion}

The findings of this research project highlight the importance of culturally sustaining environments in tertiary programmes. It is evident that at least five of the six participants had a strong sense of Māori identity. These students recognised that when they were empowered and felt safe, and the environment was right, education could enhance their cultural identity. They supported a case for strengthening the Māori cultural practices and Māori worldview in university environments. The essential elements for most of these Māori students were the inclusion of te reo and Māori content, and more Māori academic staff. Aroha expressed it this way:

Māori actually do want to be heard, do want to be noticed. [We] just need the tools and somebody to get out there and give it to us ... I think as Māori we need to get over being shy because I guess that allows other cultures to take over when it's something that's ours ... we have to be really brave, have courage to speak out to non-Māori. (Interview, May 24, 2013)

When BPE programmes, and other university programmes like these, include Te Ao Māori, they create opportunities for Māori to first and foremost experience success as Māori. The strong link noted between the use of te reo and the inclusion of Māori knowledge in courses is one obvious way to do this; the whānau support network is another. In a BPE programme, especially as it is focused on teacher education, a culturally sustaining environment that includes Māori games, Māori research and culturally inclusive pedagogical approaches is essential. As Hokowhitu (2004) argues, "Māori inclusive physical education practices need to decolonise 
teachers, that is, engender in teachers a belief that Māori culture has something to offer 'modern' society"' (p. 79).

However, in the context of this programme's goals it is necessary to recognise the complexity of the learning and teaching environment. We must consider not just what these six students bring to and experience in the tertiary environment, but how it impacts on all students. Five of these six students presented a common voice, and an important outcome is that we are able to learn from their perceptions of their Māori identity in the programme. Most of all, we are able to recognise the strong bond that a collective sense of ethnic identity brings to the learning context. The need for socialpsychological anchors is a common thread, as is a sense of belonging and the encouragement given by authentic role models and mentors. These students felt that only Māori have a truly embodied understanding of what it is like to be Māori and therefore only Māori lecturers should teach Māori specialist courses.

But what about Hera, the Māori student who, although she self-identified as Māori, was not readily accepted as being Māori by either society or-and this was more important for her-her fellow Māori peers? Although Hera valued the use of te reo and also recognised the social-psychological strength of the whānau group, she did not speak te reo and was not part of the whannau group within the BPE programme because she perceived that she was not Māori enough. Both her individual life experiences and social pressures had worked to dissociate her from identifying as Māori during her formative years. Hera's situation exemplifies Durie's reasons for calling for a contemporary valuing of self-identification, including that of self-identity as Māori.

With $20 \%$ of the students in the BPE programme being Māori, the majority of the students were obviously non-Māori. As Legge (2008) observed, sadly these students had had little exposure to Māori culture, and her aim was to include Māoritanga in the curriculum to capture a Māori worldview. Perhaps this could be viewed as a bridge for Hera to rediscover her Māoriness and also to encourage students to think about how cultural identity can be embodied differently and how those keen to rediscover or develop their Māori identity can do so in a tertiary environment.

Perhaps Legge (2008), as a Pākehā lecturer, was an appropriate role model to ask "nonMāori to reflect on their attitudes relating to Māori and the colonisation process, to discover their identity; and to understand that facing up to cultural difference is a personal challenge in which we all have agency" (p. 89). In this way Legge was attempting to address cultural and ethnic inequities, and this could be viewed as a positive form of role modelling for students who aspire to be teachers. This perspective should be considered in conjunction with those of the student participants in this research and serves to demonstrate the complexity of teaching and learning contexts.

At an aspirational level, A. Durie (1998) argues, "Once formal education is conceived of as an empowering rather than a subordinating process, an important barrier to success will be overcome" (p. 297). For the Māori students in this research project this empowerment would mean introducing a deeper understanding of Māori identity and what it means to be Māori through the infusion of te reo and tikanga in programmes, as well as having Māori role models teaching on programmes.

\section{Glossary}

$\begin{array}{ll}\text { Aotearoa } & \begin{array}{l}\text { Māori name for New } \\ \text { Zealand; lit., "land of the } \\ \text { long white cloud" }\end{array} \\ \text { e noho } & \text { sit down } \\ \text { e tu } & \text { stand up } \\ \text { haere mai } & \text { come here } \\ \text { hapu } & \text { subtribe } \\ \text { iwi } & \text { tribe }\end{array}$

kai moana seafood 


\begin{tabular}{|c|c|c|c|}
\hline $\begin{array}{l}\text { Kaupapa Māori } \\
\text { theory }\end{array}$ & $\begin{array}{l}\text { research theory focused } \\
\text { around the body of } \\
\text { knowledge that is specific } \\
\text { to Māori }\end{array}$ & tangihanga & $\begin{array}{l}\text { weeping, crying, funeral, } \\
\text { rites for the dead; one } \\
\text { of the most important } \\
\text { institutions in Māori }\end{array}$ \\
\hline Kōhanga reo & $\begin{array}{l}\text { total immersion Māori } \\
\text { Early Childhood Centre }\end{array}$ & & $\begin{array}{l}\text { society with strong } \\
\text { cultural imperatives and }\end{array}$ \\
\hline $\begin{array}{l}\text { Kura Kaupapa } \\
\text { Māori } \\
\text { manaakitanga }\end{array}$ & $\begin{array}{l}\text { total immersion Māori } \\
\text { primary school } \\
\text { process of showing respect, } \\
\text { generosity and care for } \\
\text { others }\end{array}$ & Te Ao Kori & $\begin{array}{l}\text { protocols } \\
\text { the world of movement; } \\
\text { learning through Māori } \\
\text { movement, customs and } \\
\text { language }\end{array}$ \\
\hline Māori & $\begin{array}{l}\text { Indigenous people of New } \\
\text { Zealand }\end{array}$ & $\begin{array}{l}\text { Te Ao Māori } \\
\text { te reo }\end{array}$ & $\begin{array}{l}\text { Māori worldview } \\
\text { the [Māori] language }\end{array}$ \\
\hline $\begin{array}{l}\text { Māoritanga } \\
\text { marae }\end{array}$ & $\begin{array}{l}\text { Māori culture } \\
\text { courtyard of a Māori } \\
\text { meeting house, usually } \\
\text { including the buildings } \\
\text { around it }\end{array}$ & $\begin{array}{l}\text { tikanga Māori } \\
\text { waka } \\
\text { whānau } \\
\text { whanaungatanga }\end{array}$ & $\begin{array}{l}\text { Māori beliefs, customs and } \\
\text { lifestyle } \\
\text { canoe } \\
\text { family } \\
\text { relationship, sense }\end{array}$ \\
\hline $\begin{array}{l}\text { mātauranga } \\
\text { Māori }\end{array}$ & Māori knowledge & & $\begin{array}{l}\text { of connection or } \\
\text { belonging resulting from }\end{array}$ \\
\hline noho marae & staying at a marae & & responsibilities towards, \\
\hline Pākehā & $\begin{array}{l}\text { New Zealanders of } \\
\text { European descent }\end{array}$ & & $\begin{array}{l}\text { and support of, each } \\
\text { other }\end{array}$ \\
\hline angata whe & people of the land & whenua & land \\
\hline
\end{tabular}




\section{References}

Barcham, M. (1998). The challenge of urban Māori: Reconciling conceptions of indigeneity and social change. Asia Pacific Viewpoint, 39(3), 303-314. http://doi.org/dx9k8k

Bevan-Brown, J. (2003). The cultural self-review: Providing culturally effective, inclusive, education for Māori learners. Wellington, New Zealand: NZCER Press.

Bishop, R., Berryman, M., \& Richardson, C. (2001). Te Toi Huarewa. Retrieved from http://www.educationcounts.govt.nz /publications/maori_education/maori-medium -education/5383

Borell, B. (2005). Living in the city ain't so bad: Cultural identity for young Māori in South Auckland. In J. H. Liu, T. McCreanor, T. McIntosh, \& T. Teaiwa (Eds.), New Zealand identities: Departures and destinations (pp. 191-206). Wellington, New Zealand: Victoria University Press.

Broughton, J. (1993). Being Māori. New Zealand Medical Journal, 106(968), 506-508.

Durie, A. (1998). Emancipatory Māori education: Speaking from the heart. Language, Culture and Curriculum, 11(3), 297-308.

Durie, M. H. (1995). Te Hoe Nuku Roa framework: A Maori identity measure. Journal of the Polynesian Society, 104(4), 461-470.

Durie, M. H. (2003). Launching Māori futures. Wellington, New Zealand: Huia.

Giles, D. (1995). The educational ideology of Bethlehem College (Unpublished masters thesis). Massey University, New Zealand.

Gorinski, R., \& Abernethy, G. (2007). Māori student retention and success: Curriculum, pedagogy and relationships. In T. Townsend \& R. Bates (Eds.), Handbook of teacher education (pp. 229240). New York, NY: Springer. http://doi.org/ dkn6r6

Greenwood, J., \& Brown, L. (2008). The treaty, the institution and the chalk face: An institution-wide project in teacher education. In T. Townsend \& R. Bates (Eds.), Handbook of teacher education (pp. 67-78). New York, NY: Springer.

Hokowhitu, B. (2004). Challenges to state physical education: Tikanga Māori, physical education curricula, historical deconstruction, inclusivism and decolonization. Waikato Journal of Education, 10, 71-83.

Legge, M. (2008). A snapshot of place based learning in a marae context: An autoethnographic account.
New Zealand Journal of Outdoor Education: Ko Tane Mahuta Pupuke, 2(4), 87-102.

McIntosh, T. (2005). Māori identities: Fixed, fluid, forced. In J. H. Liu, T. McCreanor, T. McIntosh, \& T. Teaiwa (Eds.), New Zealand identities: Departures and destinations (pp. 38-51). Wellington, New Zealand: Victoria University Press.

Meredith, P. (2004). A half-caste on the half-caste in the cultural politics of New Zealand (Unpublished $\mathrm{PhD}$ thesis). University of Waikato, Hamilton, New Zealand.

Nakhid, C. (2006). Ethics and the obstruction of social justice for Māori and Pasifika (Pacific Islands) students in tertiary institutions in Aotearoa (New Zealand). Race Ethnicity and Education, 9(3), 295-305. http://doi.org/c4qr7z

Pihama, L. E. (2001). Tihei mauri ora: Honouring our voices. Mana wahine as a Kaupapa Māori theoretical framework (Unpublished PhD thesis). University of Auckland, New Zealand.

Rata, E., O’Brien, P., Murray, R., Mara, D., Gray, S., \& Rawlinson, C. (2001). Diversity. In V. Carpenter (Ed.), Theory in practice for educators (pp. 189-209). Palmerston North, New Zealand: Dunmore Press.

Ritchie, J. E. (1963). The making of a Māori. Wellington, New Zealand. Reed.

Shield, R. W. (2004). The retention of Indigenous students in higher education: Historical issues, federal policy, and Indigenous resilience. Journal of College Student Retention: Research, Theory and Practice, 6(1), 111-127. http://doi.org/ b6zs8r

Smith, W. (1999). Student subjectivity, socialisation and school physical education: A case study of an Auckland secondary school physical education programme (Unpublished master's thesis). Deakin University, Victoria, Australia.

Smith. W. (2008). Physical education teacher education and the programmatic and personal effects of institutional change (Unpublished PhD thesis). University of Queensland, Australia.

Statistics New Zealand (2013). 2013 Census QuickStats about Māori. Retrieved from http://www.stats .govt.nz/Census/2013-census/profile-and -summary-reports/quickstats-about-maori -english/population.aspx

Taiaroa, H. (2007). Weaving the contemporary position of matauranga Māori within nursing practice (Unpublished $\mathrm{PhD}$ thesis). Victoria University of Wellington, New Zealand.

Walker, R. (1989). Māori identity. In D. Novitz 
\& B. Willmott (Eds.), Culture and identity (pp. 35-52). Wellington, New Zealand: Bookprint Consultants.
Webber, M. (2008). Walking the space between: Identity and Māori/Pakeha. Wellington, New Zealand: NZCER Press. 